\title{
Kajian Pendidikan Karakter Berbasis Religi dalam Menangani Problematika Kenakalan Anak SDN Gadang 1 Malang
}

\author{
Prihatin Sulistyowati ${ }^{1}$, Vera Hayatun Sunnah ${ }^{2}$, Dwi Agus Setiawan ${ }^{3}$ \\ Program Studi Pendidikan Guru Sekolah Dasar, Universitas Kanjuruhan Malang, Indonesia \\ prihatinsulistyowati@unikama.ac.id
}

\begin{abstract}
Abstrak
Penelitian ini bertujuan untuk mengetahui pendidikan karakter berbasis religi sebagai upaya guru dalam menangani problematika kenakalan anak di Sekolah Dasar Negeri Gadang 1 Malang, Kecamatan Sukun, Kota Malang. Penelitian menggunakan pendekatan kualitatif deskriptif dengan jenis Studi Kasus. Subjek penelitian adalah siswa, guru kelas I sampai VI, guru pelajaran pendidikan agama Islam, Kristen, dan Budha, serta kepala sekolah. Teknik pengumpulan data adalah observasi, wawancara, dan dokumentasi. Analisis data meliputi pengumpulan data, reduksi data, display data, dan penarikan kesimpulan. Teknik pengecekan keabsahan data dengan triangulasi sumber dan teknik. Hasil penelitian menunjukkan Pelaksanaan pendidikan karakter berbasis religi melalui pengembangan diri dan budaya sekolah di SDN Gadang 1 Malang cukup baik dan berhasil dijalankan melalui kegiatan rutin, spontan, keteladanan guru, pembimbingan, pendekatan, perhatian intensif pada siswa, dan pengkondisian sekolah yang berupaya dalam menangani problematika kenakalan anak agar semakin menurun. Hasil penelitian menjadi bahan kajian dalam pendidikan karakter yang lebih baik lagi.
\end{abstract}

Kata Kunci: Pendidikan Karakter, Berbasis Religi, Problematika Kenakalan Anak

\begin{abstract}
This study aims to know religious character-based education as an effort of teachers in handling the problematic of child mischief in Gadang State Elementary School 1 Malang, District Sukun, Malang. The research used descriptive qualitative approach with Case Study type. The subjects of the study were students, class I to VI teachers, Islamic, Christian, and Buddhist education teachers, and principals. Data collection techniques are observation, interview, and documentation. Data analysis includes data collection, data reduction, data display, and conclusions. Technique checks data validity with source triangulation and technique. The results showed that the implementation of religious-based character education through selfdevelopment and school culture in SDN Gadang 1 Malang is quite good and successfully run through routine, spontaneous activities, teacher exemplar, guidance, approach, intensive attention to students and school conditioning that seeks in dealing with child's misbehavior problems declining. The results of research into study materials in character education is better.
\end{abstract}

Keywords: Character Education, Religion Based, Child Delinquency Problematic

\section{PENDAHULUAN}

Pendidikan merupakan suatu proses yang dilakukan manusia secara terus-menerus untuk menyempurnakan diri dari kekurangan dan keterbatasan yang dimilikinya. Tujuan utama dari pendidikan diataranya menjadikan siswa pribadi yang takwa kepada Tuhan Yang Maha Esa dan memiliki kepribadian yang utuh. Salah satu upaya untuk memperkuat karakter bangsa yaitu menerapkan pendidikan karakter dimanapun seseorang itu berada, baik di lingkungan keluarga, sekolah, atau masyarakat. Pendidikan karakter adalah suatu sistem penamaan nilai-nilai karakter yang meliputi komponen pengetahuan, kesadaran, dan tindakan untuk melaksanakan nilai-nilai tersebut (Haryati,2017). Pengembangan karakter dapat dilakukan melalui pengembangan pengembangan karakter individu seseorang yang secara sadar dilalui dengan suatu proses.Secara akademik pendidikan karakter sering disamakan dengan pendidikan nilai, 
moral, dan akhlak yang bertujuan mengembangkan kemampuan peserta didik untuk memberikan keputusan baik dan buruk, memelihara apa yang baik dan mewujudkan kebaikan itu dalam kehidupan sehari-hari dengan sepenuh hati (Zuchdi,2010). Sedangkan secara spesifik bahwa pendidikan karakter yang berbasis nilai religi mengacu pada nilai-nilai dasar yang terdapat dalam agama (Siswanto,2013). Dalam pendidikan karakter mengajarkan kebiasaan cara berpikir dan perilaku yang membantu individu untuk hidup dan bekerja bersama sebagai keluarga, masyarakat, bernegara, serta membantu individu untuk membuat keputusan yang dapat dipertanggung jawabkan. Bergesernya karakter anak pada zaman sekarang juga dipengaruhi oleh kebiasaan anak bermain game dalam gadget sehingga hal ini perlu diperhatikan baik oleh orang tua maupun guru di sekolah (Nur:2013)

Terdapat 18 nilai karakter yang dikembangkan dalam pendidikan karakter diantaranya religius, toleransi, jujur, disiplin, kerja keras, kreatif, mandiri, demokratis, rasa ingin tahu, semangat kebangsaan, cinta tanah air, menghargai prestasi, bersahabat atau komunikatif, cintai damai, gemar membaca, peduli lingkungan, peduli sosial, dan tanggung jawab (Kemendiknas,2011). Diantara nilai-nilai karakter tersebut, nilai religius merupakan salah satu nilai utama dan aspek yang sangat penting karena keyakinan seseorang terhadap kebenaran nilai yang berasal dari agama yang dipeluknya bisa menjadi motivasi kuat dalam membangun karakter. Misalkan, hal tersebut dapat diketahui dari hubungan pendidikan karakter dengan mata pelajaran akhlak yang artinya semakin baik akhlak siswa maka semakin baik pula karakter yang ada pada siswa tersebut, begitu pula sebaliknya (Febriana,2013).Selain dengan mata pelajaran akhlak, pendindikan karakter juga dapat diketahui dari hubungannya dengan budi pekerti. Hal tersebut sesuai dengan hasil peneliti (Sunusi,2016) yang menyatakan bahwa hubungan antara pendidikan karakter dengan budi pekerti terkategori juga cukup baik. Dengan demikian, siswa harus mendapatkan pendidikan yang menyentuh pendidikan dimensi dasar kemanusiaan. Dimensi dasar kemanusiaan tersebut mencakup tiga hal paling mendasar yaitu afektif (perasaan), kognitif (pengetahuan), dan psikomotorik (perilaku).

Namun pada kenyataan saat ini, sayang sekali yang mencerminkan manusia yang beragama tidak selalu terbangun dalam diri setiap orang walaupun dirinya memiliki agama. Hal ini terjadi karena kurangnya kesadaran dalam keberagamannya. Lebih menyedihkan lagi apabila seseorang beragama hanya sebatas pengakuan saja namun dalam praktek kehidupan sehari-hari sama sekali tidak bersikap, berpandangan, dan berperilaku yang sesuai dengan ajaran agama yang dianutnya (Azzet,2011). Oleh karenanya, pendidikan karakter berbasis nilai religius menjadi salah satu upaya dalam rangka mengatasi degradasi moral yang terjadi pada generasi penerus di Indonesia.Salah satunya pada problematika kenakalan anak SD. Dari kegiatan pembentukan pendidikan karakter yang diterapkan melalui program pengembangan diri dan budaya sekolah (Judiani:2010) merupakan upaya mengetahui pendidikan karakter berbasis religi sebagai upaya guru dalam menangani problematika kenakalan anak dalam proses untuk membantu siswa agar dapat menerapkan hal baik dimanapun siswa berada. Proses kegiatan yang baik itu lah yang dapat mencapai tujuan yang diinginkan dan terbentuknya interaksi yang positif antara guru dan siswa. Selain melalui program pengembangan diri dan budaya 
sekolah, pendidikan karakter juga dapat diterapkan melalui pengembangan model pendidikan karakter terintegrasi dalam pembelajaran bidang studi di Sekolah Dasar. Model pendidikan karakter yang efektif adalah model yang menggunakan pendekatan komprehensif melalui berbagai bidang studi (Darmiyati,2010). Semua warga sekolah dan orangtua siswa serta pemuka masyarakat juga perlu berkerja sama secara kolaboratif dalam melaksanakan program pendidikan karakter.

\section{METODE}

Penelitian ini menggunakan pendekatan kualitatif deskriptif dengan jenis Studi Kasus. Penelitian deskriptif adalah penelitian yang bertujuan untuk menjelaskan atau mendeskripsikan suatu keadaan, peristiwa, objek, apakah orang atau segala sesuatu yang terkait dengan variabel-variabel yang dijelaskan baik dengan angka-angka maupun kata-kata (Moleong,2012).Waktu dalam penelitian ini dilakukan dari bulan Maret sampai April 2018 di SDN Gadang 1 Malang, Kecamatan Sukun, Kota Malang. Tugas peneliti yang pertama yaitu merancang yang diteliti, membuat instrument penelitian, kemudian mengambil data, menganalisis data, serta menyusun laporan. Subjek penelitian adalah siswa, guru kelas I sampai VI, guru pelajaran pendidikan agama Islam, Kristen, danBudha, serta kepala sekolah. Data yang terdiri atas data tentang pelaksanaan pendidikan karakter berbasis religi menggunakan instrumen observasi dan wawancara, serta data dokumentasi berupa gambar atau foto pelaksanaan pendidikan karakter berbasis religi sebagai upaya guru dalam menangani problematika kenakalan anak. Analisis data menurut Miles dan Huberman dalam (Sugiyono,2015) meliputi: 1) Pengumpulan data, langkah yang paling utama dalam penelitian dengan tujuan untuk mendapatkan data, 2) Reduksi data, tindakan menganalisis data-data yang telah didapatkan untuk digolongkan sesuai dengan kebutuhan data penelitian, membuang data yang tidak diperlukan, 3) Penyajian data, merupakan kegiatan pemaparan data hasil penelitian yang telah melewati reduksi data sehingga data tersebut sudah sesuai kebutuhan penelitian untuk diinformasikan, 4) Penyimpulan menjadi dasar dalam mengambil tindakan selanjutnya. Teknik pengecekan keabsahan data dengan triangulasi sumber dan teknik. Sedangkan tahap-tahapnya meliputi tahap pra-lapangan, tahap pekerjaan lapangan, dan tahap analisis data.

\section{HASIL DAN PEMBAHASAN}

Pada pelaksanaan pendidikan karakter berbasis religi di SDN Gadang 1 Malang cukup baik dan berhasil dijalankan melalui program pengembangan diri dan budaya sekolah. Berikut dapat dilihat dari deskripsi dan indikator nilai religius dalam pendidikan karakter pada tabel 1 dibawah ini.

\section{Tabel 1. Deskripsi dan indikator nilai religius dalam pendidikan karakter}

\begin{tabular}{|c|c|c|}
\hline Deskripsi & $\begin{array}{l}\text { Indikator } \\
\text { Sekolah }\end{array}$ & Indikator Kelas \\
\hline $\begin{array}{l}\text { Sikap dan } \\
\text { perilaku } \\
\text { patuh dalam } \\
\text { melaksanaka } \\
\text { n ajaran } \\
\text { agama yang } \\
\text { dianutnya, } \\
\text { toleran } \\
\text { terhadap } \\
\text { pelaksanaan } \\
\text { ibadah agama } \\
\text { lain, serta } \\
\text { hidup rukun } \\
\text { dengan } \\
\text { pemeluk } \\
\text { agama lain. }\end{array}$ & $\begin{array}{l}\text { 1.Merayakan hari- } \\
\text { hari besar } \\
\text { keagamaan. } \\
\text { 2.Memiliki } \\
\text { fasilitas yang } \\
\text { dapat digunakan } \\
\text { untuk beribadah } \\
\text { 3. Memberikan } \\
\text { kesempatan } \\
\text { kepada semua } \\
\text { siswa } \\
\text { untukmelaksana } \\
\text { kan ibadah. }\end{array}$ & $\begin{array}{l}\text { 1.Berdoa sebelum } \\
\text { dan sesudah } \\
\text { pelajaran. } \\
\text { 2.Memberikan } \\
\text { kesempatan } \\
\text { kepada semua } \\
\text { siswa } \\
\text { untukmelaksana } \\
\text { kan ibadah. }\end{array}$ \\
\hline
\end{tabular}

Sumber : Kemendiknas, 2010

Berdasarkan tabel 1, peneliti menggunakan deskripsi nilai religius yang dibuat oleh Kemendiknas. Deskrispsi tersebut 
JIP, Vol.8, No. 2, Edisi Agustus 2018, Hal: 37-44 Prihatin Sulistyowati ${ }^{1}$, Vera Hayatun Sunnah ${ }^{2}$, Dwi Agus Setiawan ${ }^{3}$

kemudian dijabarkan kembali menjadi indikator. Aspek sikap dan perilaku yang patuh dalam melaksanakan ajaran agama yang dianutnya dapat dijabarkan kembali menjadi indikatorindikator seperti melakukan sholat jamaah bersama sesuai jadwal yang ditentukan, melakukan program kegiatan yasinan sesuai jadwal, melakukan program kegiatan BTQ sesuai jadwal, doa bersama, dan sebagainya. Aspek toleran terhadap pelaksanaan ibadah agama lain dapat dijabarkan menjadi beberapa indikator seperti melakukan doa bersama sesudah dan sebelum pelajaran sesuai dengan agama masing-masing, memberi kesempatan siswa untuk melakukan ibadah, saling menghargai ketika teman yang lain sedang melakukan ibadah, dan sebagainya. Aspek hidup rukun dengan pemeluk agama lain dapat dijabarkan menjadi indikator seperti tidak membeda-beda teman yang beragama lain, hidup rukun dengan semua teman, memberi salam kepada semua orang ketika sedang bertemu, dan sebagainya. Pola asuh spiritual yang semakin meningkat berhubungan nyata dengan karakter (Puspitasari dkk:2015)

Dari beberapa deskripsi dan indikator tersebut dapat diketahui dari program pengembangan diri dan budaya sekolah dengan indikator nilai religi di SDN Gadang 1 Malang yang dapat diintegrasikan dalam kegiatan sehari-hari di sekolah. Melalui program pengembangan diri dalam pelaksanakan nilai religius meliputi dari kegiatan rutin, kegiatan spontan, bentuk keteladanan guru pada siswa dan pengkondisian sekolah yang berupaya dalam menangani problematika kenakalan anak agar semakin menurun(Utami,2014). Pelaksanaan lainnya juga didapat melalui mata pelajaran dengan cara menyisipkannya dalam materi pelajaran atau pesan-pesan moral dari guru dan melalui budaya sekolah yang terdiri dari budaya yang ada di kelas, sekolah, dan luar sekolah. Upaya pengembangan pendidikan karakter pada pengintegrasian dalam budaya sekolah dapat dengan kegiatan di kelas (nilai toleransi), sekolah (nilai religius), dan luar sekolah / ektrakurikuler (nilai tanggung jawab) (Alfajar,2014).

Kegiatan rutin menurut (Kemendiknas,2010) merupakan kegiatan yang dilakukan siswa secara terus menerus dan konsisten dari waktu ke waktu. Contoh kegiatan rutin yang dilaksanakan di SDN Gadang 1 Malang cukup banyak diantaranya kegiatan yang setiap hari dilaksanakan, kegiatan yang terlaksana setiap seminggu sekali, dan kegiatan yang terlaksana sesuai dengan hari-hari besar tertentu. Berdasakan hasil kegiatan yang diperoleh melalui kegiatan rutin yang dilaksanakan setiap hari yaitu sholat dhuha dan dhuhur berjamaah di mushollah, membaca do'a, asmaul husna, ayat-ayat suci Al-Qur'an di dalam kelas masing-masing sebelum memulai pelajaran, melaksanakan kegiatan ektra yang masih terkait dengan keagamaan seperti BTQ dan Al-banjari bagi siswa beragama muslim yang dilakukan setelah jam pelajaran selesai. Begitu pula dengan kegiatan rutin yang dilaksanakan oleh siswa beragama non muslim pada kegiatan seminggu sekali yaitu puja bakti yang dilaksanakan di hari jum'at pagi. Kegiatan tersebut dilaksanakan pada waktu bersamaan dengan kegiatan yang dilaksanakan oleh siswa yang beragama muslim. Jadi semisal siswa yang beragama non muslim melaksanakan puja bakti, sedangkan siswa yang beragama muslim melaksanakan istighosah bersama dengan tempat yang berbeda. Selain itu kegiatan lainnya yaitu infaq yang diikuti oleh semua siswa baik yang beragama muslim maupun non muslim. Begitu juga dengan pelaksanaan kegiatan-kegiatan lainnya yang terlaksana pada hari-hari besar tertentu. Misalkan pada perayaan Maulid Nabi, bagi semua siswa turut merayakan dengan menghadiri kegiatan tersebut di sekolah, tak terkecuali dengan 
memberikan toleran terhadap siswa yang beragama lain. Hal tersebut sesuai dengan deskripsi dan indikator pada nilai religi. Hasil dari kegiatan rutin yang diperoleh ini juga sesuai dengan hasil penelitian sebelumnya oleh Arifin (2012) yang menyatakan bahwa konsep pendidikan multikultural-religius merupakan perpaduan antara konsep yang menekankan sikap penghargaan terhadap semua perintah Allah. Perpaduan ini diharapkan dapat memunculkan bentuk pendidikan yang dapat melahirkan manusia-manusia yang humanis dan religius.

Selain kegiatan rutin, ada kegiatan spontan yang dilakukan guru terhadap siswanya di SDN Gadang 1 Malang. Kegiatan spontan menurut (Wibowo,2012) merupakan kegiatan yang dilakukan secara spontan pada saaat itu juga. Sesuai dengan hasil yang diperoleh, guru melakukan kegiatan spontan ketika siswa melakukan hal yang kurang baik dengan cara memperingati atau meluruskan hal tersebut dan memberikan penghargaan kepada siswa yang melakukan hal yang baik untuk memotivasi siswa agar mempertahankan perbuatan tersebut dan termotivasi untuk melakukan hal yang lebih baik lagi. Kegiatan tersebut spontan dilakukan dalam kegiatan pembelajaran dan di luar pembelajaran. Kegiatan spontan yang berkenaan dengan nilai religius di SDN Gadang 1 Malang yaitu mengajak siswa-siswanya untuk melakukan ibadah sesuai agama yang dianutnya, mengingatkan siswa untuk selalu berbuat baik, mendoakan dan menjenguk teman yang sedang sakit, dan saling menghargai dan menghormati pendapat orang lain tanpa memandang siapapun dia.Kegiatan spontan tersebut ditujukan untuk mendukung pelaksanaan nilai religius agar siswa lebih memahami apa yang seharusnya mereka lakukan.Hal tersebut juga sesuai dengan hasil penelitian sebelumnya oleh (Sultoni,2016) bahwa demi meningkatkan sikap religius siswa secara umum, pelaksanaan pengembangan sikap religi sangat perlu diperkaya dengan metode lain seperti penyampaian salam dengan penuh kesadaran, do'a mencari ilmu, dan teguran yang baik pada siswa yang melanggar aturan agama. Pengembangan dari penerapan nilai-nilai karakter juga sama diterapkan dari hasil penelitian sebelumnya oleh (Sobri,2015) yang menyatakan bahwa penerapan nilai karakter tersebut dikembangkan dari motto sekolah, yaitu research, reasoning, dan religius. Nilai religiusnya terdiri dari Fiqih, Aqidah dan AlQur'an. Penanaman nilai karate tersebut diterapkan dalam kehidupan sehari-hari di sekolah dan diintegrasikan ke dalam proses pembelajaran di dalam kelas.

Selanjutnya melalui bentuk keteladan guru kepada siswa. Keteladanan adalah perilaku dan sikap guru dan tenaga kependidikan yang lain dalam memberikan contoh terhadap tindakantindakan yang baik, sehingga diharapkan dapat menjadi panutan bagi siswa untuk dapat menirunya (Wiyani,2013). Berdasarkan hasilnya, contoh keteladanan yang sudah dicontohkan guru kepada siswa yaitu guru saling mendukung dan bekerjasama dalam segala hal untuk kebaikan siswa, penanaman karakter salah satu cara yang efektif dengan pemodelan atau contoh (Sudrajat:2011), keteladanan (Rohendi:2016). Misalkan mengenai pelaksanaan nilai religi yaitu ikut serta dalam berbagai kegiatan yang dilakukan siswa. Salah satunya pada saat pelaksanaan sholat berjamaah baik sholat dhuha, dhuhur, ataupun sholat jum'at, kegiatan beribadah bersama(Wuryandani:2014). Begitu juga dengan yang dilaksanakan oleh guru beragama lain. Kemudian yang terakhir dalam program pengembangan diri melalui budaya sekolah yaitu dengan bentuk pengkondisian yang diberikan sekolah demi mewujudkan visi dan misi sekolah. Peran sekolah dalam mendukung pelaksanaan nilai karakter religius dalam 
JIP, Vol.8, No. 2, Edisi Agustus 2018, Hal: 37-44 Prihatin Sulistyowati ${ }^{1}$, Vera Hayatun Sunnah ${ }^{2}$, Dwi Agus Setiawan ${ }^{3}$

pendidikan di SDN Gadang 1 Malang yaitu sangat mendukung, dilihat dari beberapa kegiatan yang sering dilaksanakan sekolah dan penerapannya pada setiap pembelajaran. Misalkan sekolah telah menyiapkan sumber daya manusia, menyiapkan sarana dan prasarana yang dibutuhkan dalam mendukung pelaksanaan nilai karakter religius contohnya adanya mushollah, tempat wudhu, alat sholat, Al-Qur'an, juz amma, dan buku yasin. Selain menyediakan fasilitas-fasilitas tersebut sekolah juga menyediakan waktu yang cukup pula kepada siswanya yang berbeda agama untuk tetap melaksanakan kegiatan yang sesuai dengan agama yang dianutnya. Pembiasaan kegiatan rutin beribadah berjamaah dan pembimbingan kerohanian untuk menanamkan nilai religius pada anak (Murniyetti:2016)

Dari proses program pengembangan diri dan budaya sekolah yang baik itulah yang dapat dijadikan upaya untuk guru dalam menangani problematika kenakalan anak. Diantaranya dapat dilakukan dengan pembimbingan, pendekatan, dan perhatian intensif pada siswa. Dengan tujuan agar dapat membelajarkan pada siswa mengenai pendidikan karakter yang lebih baik lagi. Selain itu ada juga tujuan dari penerapan teori pembiasaan dalam pembentukan karakter religi siswa di tingkat SD. Proses pendidikan karakter religi dengan memakai metode pembiasaan telah dapat meningkatkan aktifitas siswa dalam melaksanakan sholat lima waktu dan pembacaan ayat-ayat Al-Qur'an serta dapat meningkatkan karakter yang baik siswa dalam kehidupan sehari-hari(Mutakin,2014). Walaupun disadari bahwa keberhasilan teori pembiasaan ini tidak bisa dilepaskan dari peran serta guru dan orangtua di rumah.

Pembahasan mengenai pengaruh keterlibatan seorang pendidik dengan orang tua siswa juga diungkapkan oleh hasil penelitian sebelumnya oleh (Whitney dan Miriam,2014) bahwa pendidik yang berperan seperti halnya mampu bekerjasama dengan orangtua siswa akan cenderung lebih bersifat proaktif, sehingga hubungan keterlibatan antara pendidik dengan orangtua dalam tingkat kepercayaan yang dilakukan anaknya juga akan berpengaruh kepada anak tersebut. Misalkan seperti melalui komunikasi jaringan sosial yang dilakukan orang tua terhadap anaknya akan sangat mudah dalam mengidentifikasi perkembangan siswa dalam lingkup konteks etnis budaya yang berbeda. Dimensi dalam keterlibatan orang tua bervariasi dalam sebuah kancah penelitian, sehingga dalam tujuan penelitian ini adalah untuk menguji kedua perspektif antara peran keyakinan orang tua dan jaringan sosial dalam kepercayaan siswa. Serta lebih menekankan peran moral dalam bersosial komunikasi.

\section{SIMPULAN}

Berdasarkan hasil penelitian mengenai pelaksanaan pendidikan karakter berbasis religi sebagai upaya guru dalam menangani problematika kenakalan anak di SDN Gadang 1 Malang dapat disimpulkan bahwa : pelaksanaannya dapat diterapkan melalui program pengembangan diri yang dilaksanakan dari kegiatan rutin yang dilakukan setiap hari,seminggu sekali, dan pada hari-hari besar tertentu. Selain itu, juga dapat dilaksanakan dari kegiatan spontan, keteladan, dan pengkondisian. Kegiatan-kegiatan tersebut diterapkan melalui budaya sekolah diantaranya baik di dalam kelas, di sekolah, dan di luar sekolah yang berupaya dalam menangani problematika kenakalan anak agar semakin menurun. Selain itu juga dilakukan dengan pembimbingan, pendekatan, perhatian intensif pada siswa.

Saran yang dapat disampaikan dari hasil penelitian ini adalah, hendaknya bagi kepala sekolah dan guru saling mengingatkan untuk terus menerus mendampingi dan membimbing siswanya dalam menjaga kerukunan dengan siapapun, sehingga problematika kenakalan 
JIP, Vol.8, No. 2, Edisi Agustus 2018, Hal: 37-44 Prihatin Sulistyowati ${ }^{1}$, Vera Hayatun Sunnah ${ }^{2}$, Dwi Agus Setiawan ${ }^{3}$

anak tidak rentan mudah terjadi. Selain itu peran orangtua, hendaknya juga diharapkan mampu menyeimbangi penerapan pendidikan karakter yang terlaksana di sekolah dengan di rumah. Sedangkan bagi sekolah, harusnya lebih mengoptimalkan fasilitas-fasilitas yang ada untuk mendukung terlaksananya kegiatankegiatan keagamaan yang belum ada di sekolah. Sehingga diharapkan dapat menerapkannya dalam pendidikan karakter yang lebih baik lagi.

\section{DAFTAR RUJUKAN}

Alfajar, Lukman Hakim. 2014. Upaya Pengembangan Pendidikan Karakter di Sekolah Dasar Negeri Sosrowijayan. Jurnal Ilmu Pendidikan: Universitas Negeri Yogyakarta.

Arifin, Zainal. 2012. Pendidikan MultikulturalReligius untuk Mewujudkan Karakter Peserta Didik yang Humanis-Religius. Jurnal Pendidikan Islam: Universitas Islam Negeri Sunan Kalijaga.

Azzet, Ahmad Muhaimin. 2011. Urgensi Pendidikan Karakter di Indonesia. Yogyakarta: Ar-Ruzz Media.

Darmiyati, dkk. 2010. Pengembangan Model Pendidikan Karakter Terintegrasi dalam Pembelajaran Bidang Studi di Sekolah Dasar. Jurnal Cakrawala Pendidikan: Universitas Negeri Yogyakarta.

Febriana, Laily Istanti. 2013. Hubungan Pendidikan Karakter dengan Mata Pelajaran Akhlak (Studi Kasus Kelas VIII di SMP Muhammadiyah 10 Surakarta Tahun 2012/2013). Jurnal Pendidikan Agama Islam: Univesitas Muhammadiyah Surakarta.

Haryati, Sri. 2017. Pendidikan Karakter dalam Kurikulum 2013. Jurnal Pendidikan: UTM

Judiani S.2010. Implementasi Pendidikan Karakter di Sekolah Dasar Melalui Penguatan Pelaksanaan Kurikulum.
Jurnal Pendidikan dan Kebudayaan, Vol. 16, Edisi Khusus III, Oktober 2010

Kemendiknas. 2010. Bahan Pelatihan : Penguatan Metodologi Pembelajaran Berdasarkan Nilai-Nilai Budaya untuk Membentuk Daya Saing dan Karakter Bangsa. Jakarta: Kemendiknas.

Kemendiknas. 2011. Kebijakan Nasional Pendidikan Karakter Bangsa. Jakarta: Puskur Litbang Kemendiknas.

Moleong, J. Lexy. 2012. Metode Penelitian Kualitatif. Bandung: PT. Remaja Rosdakarya.

Murniyetti, Engkizar,dan Anwar F.2016. Pola Pelaksanaan Pendidikan Karakter Terhadap Siswa Sekolah Dasar. Jurnal Pendidikan Karakter, Tahun VI, Nomor 2, Oktober 2016

Mutakin, Tatan Zenal. 2014. Penerapan Teori Pembiasaan dalam Pembentukan Karakter Religi Siswa di Tingkat Sekolah Dasar. Jurnal Pendidikan Islam: Universitas Indraprasta PGRI.

Nur,Haerani. 2013. Membangun Karakter Anak Melalui Permainan Anak Tradisional. Jurnal PendidikanKarakter,Tahun III,Nomor 1, Februari 2013

Puspitasari R, Hastuti D, dan Herawati T.2015. Pengaruh Pola Asuh Disiplin Dan Pola Asuh Spiritual Ibu Terhadap Karakter Anak Usia Sekolah Dasar. Jurnal PendidikanKarakter, Tahun V, Nomor2, Oktober 2015

Rohendi Edi.2016. Pendidikan Karakter Di Sekolah. Jurnal Eduhumaniora, Vol. 3, No.1 2016

Siswanto.2013. Pendidikan Karakter Berbasis Nilai-Nilai Religius. Jurnal Pendidikan: Universitas Tarbiyah Pamekasan.

Sobri, Ahmad Yusuf. 2015. Manajemen Pendidikan Karakter Berbasis Religi di Sekolah Dasar. Jurnal Ilmu Pendidikan: Universitas Negeri Malang. 
JIP, Vol.8, No. 2, Edisi Agustus 2018, Hal: 37-44 Prihatin Sulistyowati ${ }^{1}$, Vera Hayatun Sunnah ${ }^{2}$, Dwi Agus Setiawan ${ }^{3}$

Sudrajat,Ajat.2011. Mengapa Pendidikan Karakter?. Jurnal Pendidikan Karakter,Tahun I, Nomor 1, Oktober 2011

Sugiyono. 2015. Metode Penelitian Pendidikan : Pendekatan Kuantitatif, Kualitatif, dan $R \& D$. Bandung: Alfabeta.

Sultoni, Achmad. 2016. Implementasi Kurikulum 2013 Bidang Studi Biologi dalam Mengembangkan Sikap Religius Siswa di Madrasah Aliyah. Jurnal Pendidikan Islam: Universitas Negeri Malang.

Sunusi, Syamsul. 2016. Hubungan Pendidikan Karakter dengan Budi Pekerti Siswa di SMP Negeri 2 Galesong Kabupaten Takalar. Jurnal Pendidikan Ilmu Sosial: Unirversitas Negeri Makassar.

Utami, Annis Titi. 2014. Pelaksanaan Nilai Religius dalam Pendidikan Karakter di SD Negeri 1 Kutowinangun Kebumen. Jurnal Ilmu Pendidikan: Universitas Negeri Yogyakarta.
Whitney dan Miriam. 2014. Keterlibatan Peran dan Keyakinan Orang Tua dalam Jaringan Sosial dan Kepercayaan. Terjemahan Setiawan, Dwi Agus. 2017. Yogyakarta: UNY Program Pascasarjana dalam Sajian Matakuliah Seminar Kontemporer Pendidikan.

Wibowo, Agus. 2012. Pendidikan Karakter: Strategi Membangun Karakter Bangsa Berperadaban. Yogyakarta: Pustaka Pelajar.

Wiyani, Novan Ardi. 2013.Desain Budaya Islami di SD. Jurnal Dialektika Prodi PGSD. 2 (1): 1

Wuryandani W, Maftuh B, Sapriya, dan Budimansyah D.2014. Pendidikan Karakter Disiplin Di Sekolah Dasar Cakrawala Pendidikan, Juni 2014, Th. XXXIII, No. 2

Zuchdi, Dimyati. 2010. Pendidikan Karakter dengan Pendekatan Komprehensif. Yogyakarta: Univ. Press 